\title{
EUROPE'S DISCOVERY OF THE ETHIOPIAN TAENICIDE-KOSSO
}

\author{
by \\ RICHARD PANKHURST*
}

\section{EARLY REPORTS}

EUROPE'S DISCOVERY of the Ethiopian taenicide kosso, variously known as Banksia Abyssinica, Brayera anthelmintica, and Hagenia Abyssinica, dates back to the early seventeenth century when the Jesuits first penetrated the hitherto little-explored kingdom of Prester John. The drug, and the tree from the flowers and seeds of which it was prepared, caught the attention of at least three of the missionaries, Pero Paes, a Spaniard, ${ }^{1}$ and two Portuguese, Manoel Barradas ${ }^{2}$ and Manoel de Almeida. ${ }^{3}$ The latter records that the "Coço" tree was found in "nearly all the high and cold parts" of the country, and bore "fruit like ears of corn or like the chestnut flower that we call 'lamps"." Explaining that it was "as bitter as the whin", he somewhat naively concluded that "because it is so bitter when drunk it is an excellent medicine with which to kill certain worms in the stomach". "Similar statements were made by another Portuguese Jesuit, Nicolo Godinho. ${ }^{5}$

These reports were read with interest by the seventeenth-century German scholar Job Ludolf, who has aptly been termed the founder of Ethiopian studies in Europe. Citing Godinho as his source, he notes that there grew in Ethiopia a tree "most excellent against Worms in the Belly", and that this was "a Distemper frequent among the Abessines, by reason of their feeding upon Raw Flesh. For the remedy whereof the Habessines Purge themselves once a Month with the Fruit of the Tree, which causes them to Void all their Worms"."

Such mention of the remarkable properties of kosso had, however, little or no impact on European medical thinking, for though taenia was then prevalent in many parts of the continent, and most difficult to cure, the expulsion of the Jesuits from Ethiopia in 1632-33 had rendered the country too isolated to allow access to persons in search of drugs.

*R. Pankhurst, B.Sc., Ph.D., London School of Economics and Political Science, University of London.

1 C. Beccari, Rerum Aethiopicarum scriptores occidentales, Rome, Tip de Luigi, 1913-1917, vol. 2 pp. 213, 223.

Ibid., vol. 4, p. 56.

Ibid., vol. 5, p. 216.

C. F. Beckingham and G. W. B. Huntingford, Some records of Ethiopia, 1593-1646, London, Hakluyt Society, 1954, p. 98.

${ }^{5}$ N. Godinho, De Abassinorum rebus, Lyons, H. Cardon, 1615, p. 57.

- J. Ludolf, A new history of Ethiopia, London, S. Smith, 1684, p. 51. See also, Ludolf's Historia Aethiopica, Frankfurt, J. D. Zunner, 1681, vol. 1, pp. 9, 31. 


\section{Richard Pankhurst}

The Ethiopian taenicide was nevertheless "rediscovered" in the eighteenth century by at least two other European travellers, a Czech monk Brother Remedio Prutky of Bohemia, whose account was never published, ${ }^{7}$ and a few years later by the famous Scottish explorer James Bruce. The latter, who included an engraving of a flowering branch of the tree in his Travels to discover the source of the Nile of 1790, described "Cusso" as "one of the most beautiful" as well as "one of the most useful" of trees, and, while recognizing that the infestation for which it was used resulted from the widespread habit of eating raw meat, incorrectly referred to it not as taenia or tapeworm but as ascarides or roundworm. He nevertheless rightly noted that to produce the drug a handful of seeds or flowers would be "steeped all night" in about two quarts of beer, and the potion drunk in the morning. Much taken by the medicine which was then sold in Cairo "for the use of Abyssinian and Nubian slaves and others", he expressed the view that, "having been found a gentle, safe and efficacious medicine in Abyssinia", he could not but doubt that "the superior skill of our physicians would turn it to the advantage of mankind in general, when used here in Europe". He accordingly named the tree Banksia Abyssinica after Sir Joseph Banks, the President of the Royal Society. ${ }^{8}$

Bruce, though bringing kosso to the attention of the European public, was unsuccessful in his effort to name it, for the term Banksia had a few years earlier been given by the younger Linnaeus to another plant as specified in his Supplementum plantarum of $1781 .^{\circ}$ Since the Scotsman's proposed name could not be used, the famous French biologist and botanist Jean Baptiste Lamarck chose to call the tree Hagenia Abyssinica after Dr. C. G. Hagen, a German professor of botany at Königsberg. The designation appeared in Lamarck's Dictionnaire encyclopédique de botanique of 1811, which attributes the discovery of kosso to "Brown"-evidently a typographical error for "Bruce". 10

The medicinal properties of kosso which had so impressed the Scotsman were later noticed by Nathaniel Pearce, a young Briton who lived in northern Ethiopia from 1808 to 1819 , and observed that the specific was "a strong purgative ... much celebrated for killing the tape-worm". ${ }^{11}$ His friend William Coffin, on the other hand, felt that the medicine was "not as effectual" as senna, a taenicide then much used in the Sudan. ${ }^{12}$ The reports of Pearce and Coffin duly reached Henry Salt, their patron in England, and through him Dr. Madden, a French physician in London, who was reported to have "reaped the honour" of discovering kosso, though there is no evidence of his in fact publicizing it. ${ }^{13}$

${ }^{7}$ R. Pankhurst and T. Pearson, 'Remedius Prutky's eighteenth-century account of Ethiopian taenicides and other medical treatment', Eth. med. J., 1972, 10, (1): 3-4.

${ }^{8} \mathrm{~J}$. Bruce, Travels to discover the source of the Nile, Edinburgh, 1790, vol. 3, p. 314, vol. 5, pp. 73-76 and preceding plates; ibid., Edinburgh, 1813, vol. 7, p. 100.

- J. Pereira, 'The kosso or Brayera anthelmintica', Pharm. J., 1850, 10: 15. See also, J. Pereira, Lond. J. Med., 1850, 2: 896.

${ }_{10}$ Pereira, op. cit., note 9 above, Pharm. J., p. 16; Lond. J. Med., p. 896.

$11 \mathrm{~N}$. Pearce, The life and adventures of Nathaniel Pearce, London, M. Colburn \& R. Bentley, 1831 , vol. 1, pp. 300-301.

12 Ibid., vol. 1 , p. 300.

13 Ibid., vol. 1, p. 300. 
THE INVESTIGATIONS OF DR. BRAYER

Though reports on the Ethiopian drug had been circulating in Europe, still infested with taenia, for some two hundred years, it did not attract the attention of the medical profession until the second or third decade of the nineteenth century. The first physician to interest himself in the taenicide was a Frenchman, Dr. A. Brayer, who took up a practice in Constantinople in 1816. Much fascinated with the traditional cures of the East-he quoted the legend that God had shown Adam the medicinal plants of the region-he conversed on these matters in a local café with a ninety-year-old Armenian merchant Karabet Habashi, or Karabet "the Abyssinian", who had made numerous visits to Ethiopia, and spoke to the Frenchman about its plants and their "miraculous properties". One of the waiters, it transpired, had for many years suffered from tapeworm, and, in accordance with the custom of the time, asked every doctor he met how to cure his complaint. Following their advice he had tried numerous remedies, many of which expelled part of the worm, but the symptoms soon returned as violently as before. He was in consequence extremely thin, experienced frequent lymphotomy, and was often obliged to stop work. One day the Armenian drew Brayer's attention to the afflicted man, and declared: "You see that unfortunate being, he has tried all the cures known in Europe; in Abyssinia his complaint would not last twenty-four hours, and yet he has suffered for ten years! But I wrote last year to my eldest son who travels instead of me to Abyssinia asking him to send me the specific known in that country against taenia; this worm is very common there."

Karabet went on to explain that the Ethiopians cured themselves with the flowers of a plant which he referred to by the Armenian word cabotz which, according to the Armenian medical historian Vahram Torkomian, signifies a "packet or lump of bandlets" and referred to the appearance of the taenia when expelled. ${ }^{14}$ The merchant declared that a caravan bringing the medicine should by then have arrived in Cairo where his son resided. "These flowers", he added, "will soon arrive; I will make this unfortunate wretch take them; he will be cured."

Brayer paid little attention, for he assumed that the Armenian, like many persons in the East, was merely describing some imaginary, miraculous cure, and therefore dismissed the matter from his mind, until 7 January 1820 , when the waiter came to him, smiling with joy, to say that he was perfectly cured. The flowers, he explained, had arrived two days earlier, and that very night, acting on the Armenian's instructions, he had macerated 300 grains in twelve ounces of water. Early the following morning he had drunk half the potion. The unpleasant taste and smell had occasioned him strong nausea, but an hour later he had taken the other half, and gone to bed. Subsequently he felt acute pains in the intestines, defaecated many times, and finally expelled the entire parasite. "The worm was dead; its head had been the last piece to come out", and "all the symptoms" soon "completely disappeared". The doctor, who had occasion to see the waiter for the next six months, adds that his health "improved from day to day".

${ }^{14}$ V. K. Torkomian, 'A propos de l'histoire de la plante "kousso",' Congrès internationale d'Histoire de la Médecine, Anvers, De Veijt, 1929, p. 104. 


\section{Richard Pankhurst}

Brayer was naturally much interested to see the flowers which had produced so dramatic a cure. With great difficulty he obtained some thirty grains. Bruised, almost reduced to powder, and hard to identify, he took them to Paris where he showed them to the celebrated Prussian botanist Carl Kunth, who declared that they belonged to a hitherto unknown species of Rosaceae, and described them in a paper presented to the French Société d'Histoire Naturelle in July 1822. Apparently unaware that the plant had already been named, he proposed that it be called Brayera after Dr. Brayer and anthelmintica on account of its anthelmintic qualities, and, as was the custom, added his own name as the authority. The drug was thus named Brayera anthelmintica (Kunth), and Brayer duly published an account of his discovery in a Notice sur une nouvelle plante de la famille des rosacées employée en Abyssinie which appeared in Paris in September 1822.15

Brayer's discovery aroused some interest in French and other European medical circles. Mention of kosso was made in several Paris journals, among them the Bulletin de la Société Philomatique of 1823, the Journal de Pharmacie and Archives Générales de Médecine for 1832, ${ }^{16}$ and in Germany in Heinrich Pierer's Annalen of 1822, and Philip Geiger's Magazin für Pharmacie of 1823. The drug was later also referred to in France in F. V. Merat de Vaumartoise's Dictionnaire universel de matière médicale of 1829 which noted, however, that it sometimes caused nausea. ${ }^{17}$

Brayer meanwhile continued his passionate interest in the anthelmintic which bore his name. Returning to Constantinople in 1824, he had numerous opportunities to see the waiter who had by then become a barber, and, no longer afflicted by the complaint, seemed in radiant health.

The doctor conversed further with the venerable Karabet who told him that in Ethiopia "every soldier" carried a "small bag" of kosso flowers, a little of which they mixed with their food, for otherwise "eight out of ten" would be attacked by taenia, while the rest of the population took the drug once a month to remove the parasite with which they were greatly infested.

Brayer was so fascinated by such reports, corroborated as they seemed to be by the cure he had himself witnessed, that he determined to obtain a supply of kosso to treat his interpreter's sister-in-law, Lucia, a fifty-one-year-old woman from Aleppo who had been suffering from taenia for seven years. She had come to him in 1820 when passing small pieces of worm, but had subsequently expelled fragments four and six feet long. Frightened by the parasite's apparent increase in size, she was much debilitated; her face was puffy and of sallow complexion, her stomach swollen, and her breathing difficult.

Since Karabet had no more of the drug, Brayer wrote to Drovetti, the French Consul-General in Egypt, asking him to obtain some from one of the caravans coming from Ethiopia, and also begged several doctors travelling to Egypt to search on his behalf, but all such efforts proved fruitless. Not long afterwards, however, Brayer learnt from Karabet that the waiter-cum-barber might not have used all the

\footnotetext{
${ }^{15}$ A. Brayer, Notice sur une nouvelle plante de la famille des rosacées employée . . . en Abyssinie, Paris, 1822, passim.

16 J. Pharm., 1823, 9: 160; Archs. gén. Méd., 1823, 1: 434-436.

17 Lond. Edinb. mthly J. med. Sci., 1850, $11: 80$.
} 


\section{Europe's discovery of the Ethiopian taenicide-kosso}

taenicide originally given to him. Inquiry established that, fearing another attack, he had indeed retained some, but only enough for one and a half doses. One dose he insisted on keeping for himself, and was therefore only willing to spare half a dose.

On obtaining this meagre quantity on 23 November 1823, Brayer set to work without delay. At eight-thirty that night he weighed it, and found that it amounted to only seventy-five grains, or a quarter of that used earlier. He then placed it in thirty-five drachms of cold water, and left it overnight. By the morning it had absorbed about half the liquid which had become a yellowish brown, and, being too thick to be easily drunk, he added ten more drachms of water. At nine o'clock he stirred the mixture, and gave it to the patient who then rinsed her mouth, and, without asking permission, ate a few candied fruits. Ten minutes later she felt a pain in the stomach, became full of wind and belched frequently. At twelve-thirty she passed a first piece of tapeworm three inches long, and at three in the afternoon a larger fragment three and a half feet long. It was shiny and white, and continued to move even after being washed several times.

At about this time Lucia reported feeling in her rectum the pressure of a roundish object which seemed to want to go out, but she could not expel it. Brayer thereupon administered two ounces of castor oil and later several spoonfuls of boiled rice. At six-thirty the patient passed an immense piece of tapeworm, fifteen feet long, and was more comfortable. Brayer washed the parasite, but searched in vain for its head. By the next morning the patient seemed perfectly recovered.

Brayer, who kept Lucia under close observation, found that her general health was greatly improved. Having failed to evacuate the entire tapeworm she was, however, soon in difficulty. She reported on 15 February 1825, that she was once more passing pieces of parasite. Brayer who could not obtain any more kosso, was unable to repeat the treament, and Lucia, unwilling to submit to any other cure, remained untreated.

Subsequently, in the autumn of 1827, the doctor determined to travel to Egypt in quest of kosso, and made up his mind that if he could not find it he would go to Ethiopia to obtain seeds of the tree and sow them in southern France. The times were, however, unfavourable, for the sea south of Constantinople was infested with pirates, and he had sadly to abandon his proposed voyage. On returning to France he nevertheless continued to urge the value of Brayera anthelmintica. He sent copies of his Notice to a scientific mission the French government was despatching to Egypt, and in his memoirs of 1836, Neuf années d Constantinople, gave an account of his treatment of Lucia as "a new proof of the efficacy" of the traditional Ethiopian taenicide. ${ }^{18}$

\section{INCREASING EUROPEAN INTEREST}

Increasing contacts with Ethiopia in the 1830s and 1840s led to growing interest in that country and its materia medica. One of the first travellers of this period to describe kosso was the German naturalist Edouard Rüppell, who discovered in 1831-33 that it was "very effective", an ounce and a half constituting a "remarkably quick and sure" means of expelling tapeworm. Unlike Brayer he recognized that

${ }^{18}$ A. Brayer, Neuf années à Constantinople, Paris, Bellizard, 1836, vol. 2, pp. 427-444. 


\section{Richard Pankhurst}

the anthelmintic seemed to achieve only a temporary cure, but considered that it "deserved pharmaceutical attention in Europe". ${ }^{19}$ The French Saint Simonians, Edmond Combes and Maurice Tamisier, who arrived in Ethiopia in 1835, were more sceptical. Aware of Brayer's claims, they inquired why, if the drug were so successful, had the Ethiopians not delivered themselves of the parasite, and, noting that European physicians in Egypt were then prescribing kosso, gave it as their own opinion that though it expelled "a large quantity" of the worm it never actually killed it. ${ }^{20}$ Samples of kosso, albeit in a very broken form, were shortly afterwards brought to Germany where a certain Herr Engelman of Stuttgart informed a Munich pharmaceutical publication in 1839 that the drug, which he erroneously referred to as Bracera anthelmintica, was not usually effective in expelling the worm in its entirety, and that doses had therefore to be repeated every two or three months. ${ }^{21}$

Interest in the taenicide was, however, aroused by several other travellers. The French linguist Antoine d'Abbadie reported in 1838 that it by then enjoyed a great reputation in Egypt as well as in Ethiopia, ${ }^{22}$ and sent samples to several of his compatriots, among them a chemist, S. Martin, who in 1840 analysed its contents in the Journal de Chimie Médicale. ${ }^{23}$ D'Abbadie's "new taenicide" was considered so valuable that information on it was given in Dr. A. Bouchardat's Annuaire de thérapeutique de matière médicale of $1841 .{ }^{24}$

Another French traveller concerned with the drug was Dr. L. R. Aubert-Roche, ${ }^{25}$ who had contracted tapeworm in Ethiopia and on returning to France treated himself with kosso. In a communication to the French Académie Royale de Médecine, he explained on 23 February 1841, that two years previously he had ground sixteen grammes of flowers, mixed them with honey and wine, instead of the hydromel often used in Ethiopia, and taken them in the evening on an empty stomach. The next morning he drank thirty-two grammes of Sedlitz powder in water, and passed a tapeworm three metres long, in many pieces but with no sign of its head. Subsequently becoming aware that he was still suffering from the parasite, he repeated the dose, and once more passed numerous segments, but again without the head, as a result of which the infestation soon returned. Deciding to change the treatment, he began more or less as before with a dose of kosso which expelled many pieces of the parasite. Three days later he drank Sedlitz to free his intestines of faecal matter, and then took a second dose of the taenicide, followed by further Sedlitz, which caused him to pass another thirty-five centimetres of worm. Though the head was again not seen, a year had elapsed without any more sign of the complaint. This led him to believe that it

19 E. Rüppell, Reise in Abyssinien, Frankfurt, S. Schmerber, 1840, vol. 2, p. 55.

${ }^{20}$ E. Combes and M. Tamisier, Voyage en Abyssinie, Paris, Desessart, 1838, vol. 1, pp. 272-276.

21 'Beitrag zur Kenntnis Abyssinischer Arzneimittel', Repertorium für die Pharmazie, 1839, pp. 367-372; G. C. Wittstein, 'Chemische üntersuchung der Bracera anthelminthica', ibid., 1840, pp. 24-35.

28 'Mémoire de $M$. de docteur L. Aubert, relatif à trois substances anthelmintiques d'usage en Abyssinie', Bull. Acad. roy. Méd., 1840-1841, 6: 497. See also A. d'Abbadie, Dictionnaire de la langue amarifiña, Paris, F. Vieweg, 1882, col. 613.

23 J. Chim. méd., 1840, 6: 279.

${ }^{24}$ Annuaire de thérapeutique de matière médicale, 1841, pp. 140-141.

${ }^{25}$ On this traveller see G. Malécot, Les voyageurs français et les relations entre la France et l'Abyssinie de 1835 à 1870, Paris, Société Française d'Histoire d'Outre-Mer, 1972, pp. 13-18. 


\section{Europe's discovery of the Ethiopian taenicide-kosso}

was necessary to take two doses of kosso, and a couple of light purges, with an interval of a few days between them. Because of the difficulty in obtaining the taenicide, he urged the French government, which then had scientists in Ethiopia, to charge them to obtain seeds and small plants of kosso which he felt would easily acclimatize themselves in France. ${ }^{26}$ Support for the drug was also voiced by Dr. Mérat, the rapporteur, who, having obtained some of d'Abbadie's flowers, had successfully administered them to a woman who had long suffered from the parasite. ${ }^{27}$

Even greater enthusiasm for kosso was expressed by King Louis Philippe's envoy to Ethiopia, Rochet d'Héricourt, who returned to Paris in 1840 with a small quantity of it. He declared that "all Abyssinians without exception" suffered from taenia, but that nature had happily provided them with an easy and "radical" cure in kosso, which was taken from the age of four. Admitting that the anthelmintic normally expelled only part of the worm which then grew again from the head, thus necessitating treatment every two or three months, he claimed, like Aubert-Roche, that it could be more effectively administered. In support of this he stated that in Ethiopia he had made his servants take a second dose five hours after the first, with the result that the head of the worm was in every case expelled, and on returning to Europe had thus also achieved many successful cures. ${ }^{28}$

The importance of kosso in Ethiopia, and the possibility of its proving of value in Europe, were now widely discussed. A Belgian diplomat Blondeel van Cuelebrouck learnt in 1840 that 200 Maria Theresa dollars' worth of the taenicide was being shipped from the port of Massawa every year, ${ }^{29}$ while a German Protestant missionary C. W. Isenberg noted in 1841 that the anthelmintic was "more in use among the Abyssinians than any other", and was "constantly, every two months taken by almost every Abyssinian". ${ }^{30}$ Captain W. C. Harris, leader of a British diplomatic mission in $1841-42$, also testified to the frequency with which it was used, ${ }^{31}$ while the embassy's surgeon R. Kirk called it "a most efficient" remedy which was "so indispensable" to health that it was "always found" in the "immediate vicinity" of villages. Though conceding that the frequent use of the drug led to exhaustion, prolapsus ani, and indeed the shortening of life, he reported that it had been successfully tried out on a European soldier troubled with the lumbric worm, and acted "mildly and efficaciously". As for the possibility of introducing the taenicide into the European pharmacopoeia, he observed that a "plentiful supply" could be "easily obtained" from Ethiopian merchants at Massawa, but five days' journey from the areas where it grew, while the tree, because of its "hardy character", seemed suitable for intro-

\footnotetext{
${ }^{26} \mathrm{~L}$. Aubert, 'Mémoire sur les substances anthelmintiques usitées en Abyssinie', Mém. Acad. roy. Méd., 1841, 9: 393-401; 'Mémoire de M. le docteur L. Aubert', op. cit., note 22 above, pp. 492-499. 27 Ibid., pp. 496-497.

${ }^{28}$ C. F. X. Rochet d'Héricourt, Voyage sur la côte orientale de la mer rouge, dans le pays d'Adel et la royaume de Choa, Paris, A. Bertrand, 1841, pp. 308-309.

${ }^{29} \mathrm{E}$. Blondeel van Cuelebrouck, Rapport générale de Blondeel sur son expédition en Abyssinie, Brussels, Ministère des Affaires Etrangères, 1839-1842, Annexe 34, p. 17.

${ }^{30} \mathrm{C}$. W. Isenberg, Dictionary of the Amharic language, London, Church Missionary Society, 1841 , vol. 1, p. 141.

s1 W. C. Harris, The highlands of Aethiopia, London, Longman, Brown, Green, \& Longmans, 1844 , vol. 1 , p. 398 , vol. 2 , p. 18.
} 


\section{Richard Pankhurst}

duction into northern climes. ${ }^{32}$ Such praise was, however, challenged by Charles Johnston, a British naval surgeon in Ethiopia, who observed that kosso occasioned "frequent miscarriages" and even deaths. He expressed surprise that it evoked interest in Europe, "for no civilised stomach could endure the bulk of the drug necessary to produce its effects. Even in Abyssinia", he added, "it is but barely tolerated, and let another remedy, equally efficacious ... . be introduced into that country, and the use of cosso will soon be abandoned." 33

This outburst, embodied in a little-read travel book, created less impact on the British medical profession than the return from Ethiopia of the redoubtable geographer Charles Tilstone Beke, a member of many learned societies, with his servant Hayla Giyorgis. The latter, who suffered from tapeworm, was treated by the wellknown Edinburgh physician Dr. Thomas Hodgkin, who presented a paper on the subject to the medical section of the British Association for the Advancement of Science on 28 September 1844. In what the Lancet described as a "most instructive" communication he made "some curious observations" on kosso which he remarked was so highly prized in the province of Janjaro that it was monopolized for the royal family. ${ }^{34}$

\section{ROCHET D'HERICOURT'S INITIATIVE}

European interest in the taenicide entered a new phase in 1845 when Rochet d'Héricourt returned from a second voyage to Ethiopia ${ }^{35}$ In the published account of his travels he extolled the virtues of kosso, and reproduced an engraving of a flowering branch of it, copied from Bruce, though without acknowledgement. ${ }^{36}$ The envoy brought with him no less than 1,400 pounds of the drug, or sufficient for 30,000 to 40,000 doses. Evidently more mercenary than philanthropic, he put this stock, in the hands of an agent, Messrs. Caylits, Simond, \& Co., and declared that as the sole owner of the medicine in Europe he would sell it only in a single consignment, for a guinea per ounce, or a total of 22,400 guineas. ${ }^{37}$ Whether he succeeded in getting anything like that sum is not recorded, but a year or so later a Parisian pharmacist, Boggio of 13 Rue Neuve des Petit Champs, was selling kosso, probably part of Rochet's supply, at what the Lancet termed the "enormous price" of $\mathbf{4 0}$ francs, i.e. 35 shillings, for a $4 \frac{1}{2}$ drachm dose. ${ }^{38}$ The noted British pharmacologist Dr. Jonathan Pereira reported that it was in consequence "extensively adulterated". Powder selling as kosso was in fact often made from pomegranate bark..$^{39}$

To popularize his wares Rochet presented a few samples to Dr. Mérat who reported

${ }^{82}$ R. Kirk, 'Medical report on the kingdom of Shoa', Trans. med. and phy. Soc., Bombay, 1843, 7: 22-23.

as C. Johnston, Travels in southern Abyssinia, London, J. Madden, 1844, vol. 2, pp. 271-273.

s4 Lancet, 1844, ii: 55-57; Med. Times, 1844, 13: 74-75; Report of the British Association for the Advancement of Science, 1844, 2: 85. See also E. H. Kass and A. H. Bartleet, 'Thomas Hodgkin, M.D. 1798-1866; an annotated bibliography', Bull. Hist. Med., 1969, 63: 158.

${ }^{35}$ Malécot, op. cit., note 25 above, pp. 67-71.

36 C. F. X. Rochet d'Héricourt, Second voyage sur les deux rives de la mer rouge, dans le pays des Adels et le royaume de Choa, Paris, A. Bertrand, 1846, p. 346 and plate opposite.

${ }^{37}$ Pereira, op. cit., note 9 above, Pharm. J., pp. 17, 20, 23; Lond. J. Med., pp. 897, 899, 901.

${ }^{83}$ Lancet, 1850, ii: 773.

so Pereira, op. cit., note 9 above, Pharm. J., p. 20; Lond. J. Med., p. 899. 


\section{Europe's discovery of the Ethiopian taenicide-kosso}

to the French Académie des Sciences on 25 May 1847, that his experiments seemed to prove the efficacy of kosso, though it would be necessary to have a "much larger quantity" to "state precisely its action" and assign it a position in the pharmacopoeia. ${ }^{40}$ Several other French physicians also obtained supplies from Rochet. One of them, M. Sandras, whose investigations were reported in the Annuaire de Thérapeutique for 1847, on a number of occasions administered doses to patients who soon expelled the whole tapeworm in pieces, usually without discomfort. Only in two cases had there been any complaint of indisposition, and there was no instance of a parasite surviving the treatment.

Kosso was also twice administered by Dr. Chomel of the Paris hospital Hôtel-Dieu who prescribed fifteen gramme doses. In the first case the patient, a healthy thirtyfive-year-old man, expressed repugnance at its taste, vomited, and had to be provided with alternative medicine. The second patient, a twenty-six-year-old man, raised no objection to the drug. It was given to him at eight-thirty in the morning, and had such rapid effect that at ten-fifteen he began passing pieces of tapeworm, one of them thirty centimetres long. Two days later a cleaner found in the patient's clothes several other pieces which formed part of the parasite's cephalic extremity. ${ }^{41}$

Such reports created considerable interest in the French medical profession, and caused several more practitioners to turn to kosso. One of the keenest was a twentyseven-year-old doctor from Toulouse who was himself suffering from taenia, and had tried all known treatments in vain. Deciding to try the Ethiopian medicine, he travelled to Paris on 26 October 1848. On the following day he took forty grammes in water, but, no motion resulting, drank a bottle of Sedlitz. An evacuation followed, with the expulsion of several pieces of the parasite. None of them showed any signs of movement, and the physician therefore concluded that kosso, unlike the other specifics he had used, actually killed the animal. Not long afterwards he passed many more fragments, one of them with the head. This cure was reported in the Journal de Médecine de Toulouse, and later in the Journal de Médecine et Chirurgie pratiques which commented that the African plant, if more diffused, would "perhaps surpass" the pomegranate root, then rated one of the most efficacious taenicides.42

Travellers to Ethiopia meanwhile continued to inform the French public of the importance of kosso. In 1846 two French officers, Captains P. Ferret and J. Galinier, gave it as their opinion that taenia could be effectively expelled if the patient took two doses with a short interval between them, ${ }^{43}$ while the report of a scientific mission of 1845-49 contained enthusiastic descriptions of kosso by a botanist, Professor Achille Richard, who called it "one of the most valuable of Abyssinian trees", and by a physician, Dr. Antoine Petit, who recalled that he had himself twice taken the drug, though its taste was so "horrible" and "disgusting" that on a subsequent occasion he chose an alternative local cure.44

\footnotetext{
40 J. Méd. Chir. prat., 1874, 18: 319. See also, Med. Times, 1847, 16: 298.

11 Annuaire de thérapeutique de matière médicale, 1847, pp. 256-258.

42 J. Méd. Chir. prat., 1850, 21 : 415.

4s P. V. A. Ferret and J. G. Galinier, Voyage en Abyssinie, Paris, Paulin, 1847, vol. 2, pp. 110-111. See also, vol. 3, p. 131.

${ }_{4}$ T. Lefebvre et al., Voyage en Abyssinie, Paris, A. Bertrand, 1845-1849, vol. 2, pp. 363-365; vol. 4, pp. 258-259; Atlas, Histoire naturelle, botanique, plate 48.
} 


\section{Richard Pankhurst}

No less influential in arousing medical awareness in kosso was Dr. Wilhelm Schimper, a German naturalist at Adwa, who sent samples to his cousin Philip Schimper, curator of the natural history museum at Strasbourg, who deposited them in the city's academy and school of pharmacy, and invited interested physicians to experiment with them. Wilhelm Schimper, who had himself investigated Ethiopian anthelmintics, observed that the "great advantage" of kosso was that it acted "very rapidly" in only four or five hours. Though granting that it did not usually remove the whole taenia from Ethiopians seriously infested, he felt it might be more successful with Europeans less prone to the complaint, and that the feeling of discomfort kosso produced in the mouth and rectum could be obviated by mixing it with other local drugs. These observations, published in the Gazette médicale de Strasbourg in 1848, were reproduced in the following year by both the Archives générales de Médecine and the Annuaire de Thérapeutique which commented that kosso was "a very good taenicide", the only pity being that it was still so expensive. ${ }^{45}$

\section{POPULARITY IN BRITAIN}

The use of kosso spread rapidly from France to Britain. The drug's first reported use in London was in March 1850, when King's College Hospital admitted an Irish servant girl with tapeworm. She complained of languor, weakness, and a ravenous appetite which had given way to permanent flatulence. Dr. George Budd, the hospital's professor of medicine and physician in charge, having obtained four doses from Dr. de Mussy, the private physician to the deposed King Louis Philippe, decided to use them because turpentine, then a popular specific against taenia, gave rise to unpleasant side-effects. The newly imported medicine was infused for ten minutes in hot water which, according to the Lancet, "made rather a thick infusion", and "looked much the colour of ergot of rye, the taste being somewhat like senna, but not so unpleasant". The potion was administered on an empty stomach because the intestines, Budd explained, were then less full, and the parasite in consequence less protected. The medicine produced neither pain nor sickness, and soon expelled a three-foot-long piece of worm with an inch and a half of neck but no head. Despite the failure to remove the parasite in its entirety, the case seemed to offer good prospects: the Lancet declared that if further trials yielded "favourable results" kosso would prove "a valuable addition to our pharmacopoeia".46

Two more cases were reported at the same hospital in the next fortnight. The first was that of a thin and anaemic forty-one-year-old woman who was purged for a week after which kosso was administered at ten in the morning, followed by a dose of magnesia and Epsom salts. In the evening she passed numerous pieces of worm, totalling two yards, and on the morrow two more fragments, one a yard and a half long, and the other somewhat shorter from near the head. The second patient, Sarah Weeler, a forty-four-year-old woman, had contracted taenia in South Africa, and for sixteen years had been passing segments at least every five days. She had tried

45 'Des médciaments employés en Abyssinie contre le ver solitaire', Gaz. méd. Strasbourg, 1848, 12: 148-149. See also, Archs. gén. Méd., 1849, 19: 235; Annuaire de thérapeutique de matière médicale, 1849 , pp. 254-258.

${ }^{46}$ Lancet, 1850, i: 339, 773. 


\section{Europe's discovery of the Ethiopian taenicide-kosso}

turpentine, pomegranate root, and a South African remedy, but all in vain. She complained of gnawing pains, discomfort in the limbs, lassitude, dimness of sight, and permanent faintness. Given kosso at nine thirty in the morning, before breakfast, just before two in the afternoon she passed two large pieces of worm, including a fragment from near the head. After being given castor oil she released several more, apparently all dead.

These two cases were interpreted as further evidence of the potency of kosso, and caused the Lancet to comment, on 20 April, that it appeared to have "an almost certain effect". Should further trials confirm Budd's findings, the journal concluded, "we shall have a fair chance of removing the unwelcome guest whenever we are called upon to promote its evacuation." 47

The only criticism of kosso at this time was directed at its cost. The Lancet observed that it was "very expensive", no less than $17 s .6 d$. a dose. ${ }^{48}$ Supplies from France were being sold by a London chemist, Mr. Hooper of 7. Pall Mall East, to hospitals for sixteen shillings and to the public for 20 shillings per treatment. ${ }^{49}$

Reports on the successful use of kosso meanwhile continued to pour in. From Guy's Hospital, Dr. (later Sir) William Gull, the noted pathologist, wrote enthusiastically to the Lancet on 20 May to announce the cure of a thirty-three-year-old sailor, who for five years had been "much troubled" with a tapeworm which had been "a source of great annoyance". The anthelmintic had been administered to him at five in the morning and three hours later he passed many pieces of the parasite constituting a total of 126 feet. They included four thread-like anterior extremities which seemed to suggest that there had been as many worms-which was most unusual-but "although carefully searched for, no terminal segments were found". Gull nevertheless declared that the "efficacy" of kosso, and "the gentleness of its action", seemed "greatly to recommend it", its only drawbacks being its "great bulk" and expense, though these, he felt sure, would in time "probably be obviated." 50

Support was also voiced by Dr. G. Armstrong of Ware, who informed the Lancet on 29 May that a year earlier he had begun treating a patient, and tried turpentine, castor oil, pomegranate, and the root of the male fern but without success. Hearing favourable reports of Budd's treatment he recommended kosso which the patient procured for "a very large sum", and after three hours voided the entire parasite, fifteen feet long, with little or no pain. "Thus", proudly affirmed Armstrong, "he got rid of a monster which the most famous anthelmintics, and the most drastic purgatives, had for twelve months been unable to dislodge."51

At King's College Hospital, meanwhile, Budd was continuing his work, and towards the end of May released details of four more cases. The first was that of a twenty-two-year-old girl from Wapping, who complaining of sickness and stomach pains, was given kosso and a dose of castor oil, after which she expelled a parasite three yards long, including its neck but not its head. The three other cases were of a

${ }^{47}$ Ibid., pp. 483, 773-774; Med. Times, 1850, 22: 296.

${ }^{48}$ Lancet, 1850, i: 483.

40 Ibid., p. 773.

${ }^{50}$ Ibid., p. 625.

${ }^{51}$ Ibid., p. 677 


\section{Richard Pankhurst}

Scottish woman four months pregnant who passed a worm five yards long; a middleaged woman of Bow who expelled one six yards long; and Samual Payne, a fortysix-year-old man, who passed one of nearly ten yards including a piece from near the head. The Lancet, which announced these cures on 25 May, again regretted that the anthelmintic was "so expensive", but commented that in view of its speed and efficacy this could "hardly be looked upon as a high price", as rapid treatment removed the need for lengthy hospitalization. The journal nevertheless added an implicit, and, in the light of subsequent events, significant word of caution, observing that it would be "extremely interesting" to "keep an eye" on the patients to ascertain whether the cures were "lasting or temporary". ${ }^{52}$

Budd for his part was, however, fully satisfied. In a lecture at his hospital he claimed that "not one" of the nine doses administered had "failed to kill and expel the worm", that in every case the head or adjacent portion had been removed, and that there was "reason to suppose" that each parasite had been "entirely destroyed". This suggested that kosso was "a very effectual remedy", "both speedy and safe", "much more efficacious" than pomegranate, and "more efficacious, as well as less disagreeable, and safer" than turpentine. ${ }^{53}$

Confirmation of these views flowed in from many parts of the country where kosso was coming into increasing use. Dr. Inglis, a physician at Halifax, announced a rapid and successful cure to the Medical Times, which published the news under the dramatic heading:

\section{KOUSSO \\ EXPULSION OF THE ENTIRE TAENIA, ONE HOUR AND A HALF AFTER THE EXHIBITION OF THE REMEDY}

The story turned on a fifty-year-old woman, Elizabeth Smith, who had been afflicted with tapeworm for a decade, and, though she had tried various remedies, suffered from indigestion, pains in the back, and faintness. She was administered kosso at eight fifteen, and a quarter of an hour later passed many segments, the "entire remaining portion", including the head, coming out at ten o'clock. On the morrow she expressed herself "perfectly free from pain". ${ }^{54}$

Another remarkably speedy cure, revealed in October by Dr. William Wood of Bethlem Hospital, was that of a thirty-two-year-old mechanic who had been incapacitated by a tapeworm which had induced weakness, drowsiness, nightmares, and such acute depression as to make him a danger to himself. Temporary relief had been obtained with turpentine, but this having failed to eradicate the parasite it was decided to turn to kosso. Three hours after taking it the patient passed a worm four yards long, apparently entire. On the following day his headache and other "disagreeable symptoms" disappeared, his appetite improved, and he slept without the "frightful dreams" which had long disturbed him. ${ }^{.55}$

Other successes were reported from the provinces. George Masfen, house surgeon

52 Ibid., pp. 643, 773-774.

${ }^{53}$ Ibid., pp. 773-774.

${ }^{54}$ Med. Times, 1850, 22: 83-84.

ss Lancet, 1851, i: 9. 


\section{Europe's discovery of the Ethiopian taenicide-kosso}

at the Staffordshire General Infirmary, released the news that a thirty-two-year-old woman admitted with tapeworm and sores in the groin had been treated with kosso, and subsequently purged with Epsom salts and senna. Twenty-six hours later she expelled the entire worm, twenty feet long. Her health soon improved, and her sores disappeared. ${ }^{56}$ An equally successful cure was announced by William Wills, a surgeon at Totnes, who informed the Lancet that a young farmer of Ipplepen had suffered from tapeworm for seven years and had "tried every remedy, as well as every person he could think of, both regular and quack", but to no avail. He had been given kosso obtained from M. Boggio, and four hours later expelled the parasite "quite dead and entire"..57

News of these achievements created great interest in the Ethiopian taenicide, and articles on it by a French physician Martin-Salon, ${ }^{58}$ and Jonathan Pereira ${ }^{59}$ appeared widely in the medical and pharmaceutical press.

Such publicity was accompanied by growing condemnation of the drug's high price. The Pharmaceutical Journal, voicing the general indignation, exclaimed on 1 October that kosso was being sold by speculators who, apparently choosing the text, "all that a man hath he will give for his life", sought to discover what was "the maximum price that avarice can extort from suffering". They operated on the assumption that a patient would give almost anything "to be released from the annoyance produced by a living tape-worm several yards in length. To a rich man . . . a cure would be cheap at almost any price, and a poor man could better afford to pay two or three guineas for a speedy cure, than to linger for several weeks in hospital." The kosso merchants were therefore taking credit for "liberality" in offering for ten or fifteen shillings per half-ounce a drug which would have yielded a fair profit at twenty shillings a pound. The traders had, however, "over-reached themselves", for "neither the public nor the profession" would submit to such "extortion", the more so as supplies were suspected to have been adulterated, and other taenicides were probably "quite as efficacious".

The monopoly price of kosso was in fact short-lived, for at about this time the British colonial surgeon at Aden, James Vaughan, "discovered" supplies in the local market. He sent a trial consignment to the London chemists, Messrs. Savory \& Moore of Bond Street, whose manager wrote to the Pharmaceutical Journal in January 1851, recalling the "extravagant" price in France, and offering "on the score of humanity" to present samples to hospitals and charities so that its qualities could be "fairly ascertained before a larger order was made". ${ }^{61} \mathrm{He}$ accordingly distributed the taenicide "with great liberality", thereby, as the Lancet declared, opening "very bright hopes" that the cost of kosso would fall, and "its benefits be spread to all classes". ${ }^{62}$

se Ibid., p. 14.

${ }^{57}$ Ibid., 1850. ii: 651.

s8 M. Martin-Salon, 'On some remedies for tape-worm and especially the "kousso", Lond. Edinb. mthly J. med. Sci., 1850, 11: 79-80.

${ }_{50}$ Pereira, op. cit., note 9 above: Pharm. J., pp. 15-22; Lond. J. Med., pp. 896-902.

0 Pharm. J., 1850, 10: 176.

1 Ibid., 1851, $11: 419$.

${ }^{62}$ Med. Times, 1850, 22: 84; Lancet, 1851, ii: 270; 1852, i: 40; Mthly J. med. Sci., 1851, 2: 304. 


\section{Richard Pankhurst}

\section{DOUBTS AND DEBATE}

The first discordant note in the chorus of acclaim for kosso was uttered at a meeting of the Medical Society of London on 22 March 1851, when Dr. Crisp, of the Metropolitan Dispensary, reported that he had given it to two children, aged six and twelve, with disquieting results. In the case of the younger child the anthelmintic had produced "no effect" at all, though three doses had been administered. In the case of the elder, the parasite was voided, with its head, but was found to be still alive. He therefore declared that kosso, though "perhaps the best remedy" available, was "not so effectual" as had been supposed. Another speaker, Mr. Chippendale, was also critical, and drew attention to the fact that in "many" of the published cases the head had not been passed. The use of other taenicides was recommended by Dr. Routh, who hazarded the opinion that there were "different kinds of taenia", and that different kinds of medicine might be required for their removal. ${ }^{63}$

Such reports and arguments notwithstanding, evidence of successful cures by kosso continued to come to light. Henry Taylor, a Sunderland surgeon, stated in the Medical Times of 24 May that the drug having been "so strongly recommended" he had prescribed it for a thirty-two-year-old man who had suffered from tapeworm for four years, and the parasite, complete and measuring upwards of eighteen feet, was expelled after six hours. ${ }^{64}$

More alarming information on the apparent inadequacy of kosso appeared, on the other hand, in the autumn when another London hospital, St. George's, revealed details on three patients admitted on 10 September, and treated by Dr. Wilson. This evidence was published by the Lancet of 20 September under the heading 'Relapse after the use of Kousso', while the Medical Times later reported it on 18 October with the title 'Kousso unsuccessful (?) in the Treatment of tape-worm'. The first, and most damaging, case was that of a thirty-one-year-old tailor from Slough who had passed pieces of tapeworm for four years. He had been treated with kosso at King's College Hospital in February when he had brought out a large piece of worm no less than thirty-seven feet long. Two months later, however, he was again infested, and was admitted to St. George's Hospital in June; he was administered kosso, after which he discharged another long portion. Nevertheless two months later he once more began passing segments, and returned to hospital where he was given his third dose of the drug, which expelled a thirteen-foot fragment, the head of which, significantly enough, had been left behind. The second case was that of a twentyseven-year-old shoemaker from Northampton who had likewise taken a previous dose of kosso, obtained from a dispensary at Windsor, which had displaced a segment seventeen feet long. Two months later, however, he again began dropping fragments, and was admitted to hospital when, on taking kosso, he expelled only a few pieces. He was therefore given a further dose, which led to the evacuation of two or three yards in broken fragments, but with no sign of the head. The third case was that of a seventeen-year-old girl, who on entering the hospital took a dose which expelled several pieces, together not more than a yard, but "no portions were found that approached to the head." 65

Lancet, 1851, i: 357; Med. Times, 1851, 23: 357.

os Ibid., pp. 562-563. 's Lancet, 1851, if: 270-271; Med. Times, 1851, 23: 562-563. 


\section{Europe's discovery of the Ethiopian taenicide-kosso}

These cases had a profound effect on medical thought. The Lancet, which observed that "few medicines" had of late been "more extolled", "more extensively announced", or "received with more favour", commented that two major questions about kosso had never satisfactorily been answered: first, whether it "possessed the power of expelling the worm with its head", and, second, whether patients "were not subject to a relapse". Earlier evidence had shown that the head was not in fact always passed, while the new cases indicated that incomplete expulsion of the worm offered "no guarantee from relapse". The journal therefore concluded that the drug's efficacy was "no higher than that of turpentine or the oil of the male fern". ${ }^{86}$

The news from St. George's Hospital was the subject of a paper by its famous registrar, Dr. Andrew Barclay, who wrote in the Medical Times that there could "scarcely remain a doubt" that kosso was as "liable to failure" as any other anthelmintic. Drawing attention to the fact that segments often continued to move after their expulsion, he pointed out that this disproved earlier assumptions that the parasite was actually killed. ${ }^{67}$

Vaughan at Aden, on reading these revelations, at once sprang to the taenicide's defence. In an article in the Lancet of 10 January 1852, he declared that the argument against kosso was by no means proven. Urging that its efficacy depended on the quality and quantity administered, he observed that he had seen "many parcels" of kosso flowers, and that these were by no means uniform, being probably of different species, obtained from different places, or collected at different times of the year. He therefore thought it advisable to produce a standard extract or oil of kosso. As for the dose required, his experience indicated that this depended on the idiosyncrasy of the patient, though he believed it was necessary to use an ounce and a half, i.e. four times more than Dr. Wilson had prescribed. He also emphasized that on account of "carelessness" of gatherers or "knavery" of sellers, supplies were often mixed with straw, stalks of other plants, etc., one ninety-pound parcel being found to contain only fifty pounds of flowers. As for the preparation of the drug, he claimed that the "most effectual mode" was to leave it "to macerate in hot, but not boiling, water for three hours", and to drink it "entire, without being strained, after a fast of several hours." 68

Though earlier exaggerated hopes for kosso had been dashed the case against it was far from proved, and its efficacy was a subject of continued discussion in medical circles. In France a noted professor of medicine, Dr. Nélaton, was quoted by the Journal de Médecine et de Chirurgie pratiques in 1854 as stating that it was "rare" for fifteen-gramme doses, particularly if repeated once or twice, not to achieve "complete success", ${ }^{99}$ while a British physician, Dr. George Paterson of Tiverton, was cited in the Monthly Journal of Medical Science as stating that kosso, though liable to "occasional failure", was a remedy of "great power" and a "valuable addition" to the pharmacopoeia. ${ }^{70}$ That same year, on the other hand, an American

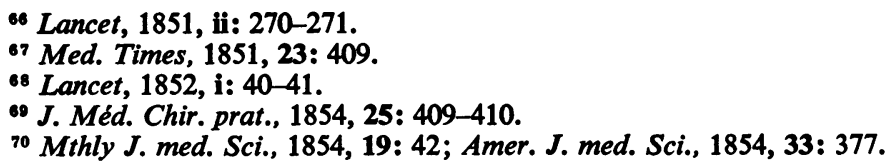




\section{Richard Pankhurst}

practitioner, Dr. Storer, informed the Boston Society for Medical Improvement that he had prescribed the drug to a middle-aged woman "without producing the slightest effect." "1

The value of kosso was likewise discussed, on 21 May of the following year, at a meeting of the Medical Society of London, where Dr. Crisp, one of its earliest critics, stated that he had administered half-ounce doses in two more cases. In the first the patient was apparently cured, but in the second, though a tapeworm thirty-three feet long was expelled, the patient soon complained of the renewed passage of fragments. In the past three and a half years, Crisp remarked, he had treated seventeen patients, eight with turpentine, four with male fern oil, three with kosso, and one with kosso and turpentine mixed, but was unable to decide the relative value of these drugs, though he believed that kosso tended to expel the parasite en masse while the other taenicides broke it up. A problem in evaluating the relative potency of these drugs, he declared, was that his patients were of the "lower ranks of life" and therefore lost sight of on leaving the dispensary. Information from private physicians in continuing contact with their patients was therefore indispensable. One such practitioner, Dr. Hare, intervened to remark that he had prescribed kosso in a number of cases, "often with decided success", and, though there was but one occasion when the parasite's entire expulsion had been established, this was not too significant as "it was difficult to detect the very small head among the faecal matter". Kosso, he felt, had "some advantage" over turpentine, and even were it found "not so effective" as some other anthelmintics, it was "less nauseous", and, in his practice, had "not been followed by bad results." "2

Continued interest in kosso was likewise demonstrated by Spencer Edmonds, a surgeon in Westmorland, who informed the Medical Times, on 24 May, that he had prescribed castor oil followed by an ounce of kosso, after which his patient had expelled a tapeworm twenty-eight feet long, with a minute extremity but no sign of the head. ${ }^{73}$ This letter prompted another from a military surgeon, R. Dane, who declared that in 1852-53 he had used half-ounce doses of the drug, followed by castor oil, on fifteen occasions, and "in every case the worm with the head was removed."74 Another, less successful practitioner, on the other hand, woefully informed the Lancet, on 22 August 1857, that he had tried kosso, and other taenicides, but "all to no use."75 This plaint called forth the journal's own opinion that an ounce of castor oil should be given on an empty stomach, followed in the morning by two drachms of powdered kosso infused in ten ounces of boiling water, a large dilution being "essential", and, finally, in the afternoon, more castor oil. ${ }^{78}$

So proceeded the great debate on kosso which was duly given a place in the British Pharmacopoeia in 1864. The taenicide, which was found to contain a yellow amorphous substance kosotoxin related to filicitic acid present in the male fern, maintained

${ }^{71}$ Ibid., p. 377.

72 Lancet, 1853, i: 547; Assoc. med. J., 1853, $1: 513$.

73 Med. Times, 1855, 31: 541 .

"I Ibid., p. 608.

${ }^{75}$ Lancet, 1857, ii: 284.

${ }^{76}$ Ibid., p. 284. 


\section{Europe's discovery of the Ethiopian taenicide-kosso}

much of its popularity in Europe until the latter part of the century when changes in medical fashion led to its gradual abandonment. ${ }^{77}$ In the country of its origin, however, the old-time anthelmintic is still widely used, ${ }^{78}$ and, despite the advent of twentieth-century drugs, one can still see a kosso-vendor walking the streets of today's Addis Ababa with huge bundles of the beautiful red flowers on whose properties Brayer, Rochet d'Héricourt, George Budd, and other Europeans had enthused over a century earlier.

\section{SUMMARY}

Kosso, the most common Ethiopian taenicide, was first reported by the Jesuits early in the seventeenth century, but, because of their expulsion, did not become known to European physicians until James Bruce "discovered" it in the late eighteenth century, and it was shortly afterwards named Hagenia Abyssinica. In the early 1800 s Dr. Brayer, a French physician in Constantinople, learnt of its use from an Armenian merchant who had visited Ethiopia, and it was for a time called Brayera anthelmintica. Many subsequent European travellers to Ethiopia spoke of it with enthusiasm, though others asked why, if it were so efficacious, did the Ethiopians have to take doses of it every few months. This, it was soon realized, was because though the drug expelled most of the parasite, the head often remained, thus enabling the worm to grow again.

The French envoy to Ethiopia, Rochet d'Héricourt, meanwhile, attempted to popularize the medicine. In 1845 he brought back 30,000 doses which he hoped to sell for some 22,000 guineas. The taenicide, which was then usually taken with a purge, soon gained a considerable reputation in France, and thereafter in Britain where Dr. George Budd of King's College Hospital claimed several spectacular cures in 1850. In the following year, however, it became apparent that these were often illusory, for a number of patients believed cured again showed symptoms of infestation. The value of the anthelmintic had therefore to be re-assessed.

${ }^{77}$ E. Littré and C. Robin, Dictionnaire de médecine, Paris, J. B. Baillière, 1873, pp. 840-841; G. C. Wittstein, The organic constituents of plants and vegetable substances and their chemical analysis, Melbourne, McCarron, Bird, 1878, pp. 115-116; F. A. Flückiger and D. Hanbury, Pharmacographia. $A$ history of the principal drugs of vegetable origin met with in Great Britain and British India, London, Macmillan, 1879, p. 25; H. Power and L. W. Sedgwick, The New Sydenham Society's lexicon of medicine and allied sciences, London, New Sydenham Society, 1882, vol. 2 [no pagination], entry kosso; J. M. Watt and M. G. Breyer-Brandwijk, The medicinal and poisonous plants of Southern and Eastern Africa, Edinburgh and London, E. \& S. Livingstone, 1962, p. 889; R. Benigni, C. Capra, and P. E. Cattorini, Piante medicinali. Chimica, farmalogia e terapia, 2 vols., Milan, Inverni and Della Beffa, 1962-64, vol. 2, pp. 797-800.

${ }^{78}$ R. Pankhurst, 'The traditional taenicides of Ethiopia', J. Hist. Med., 1969, 24: 323-330. 